\title{
Le mélanomane.
}
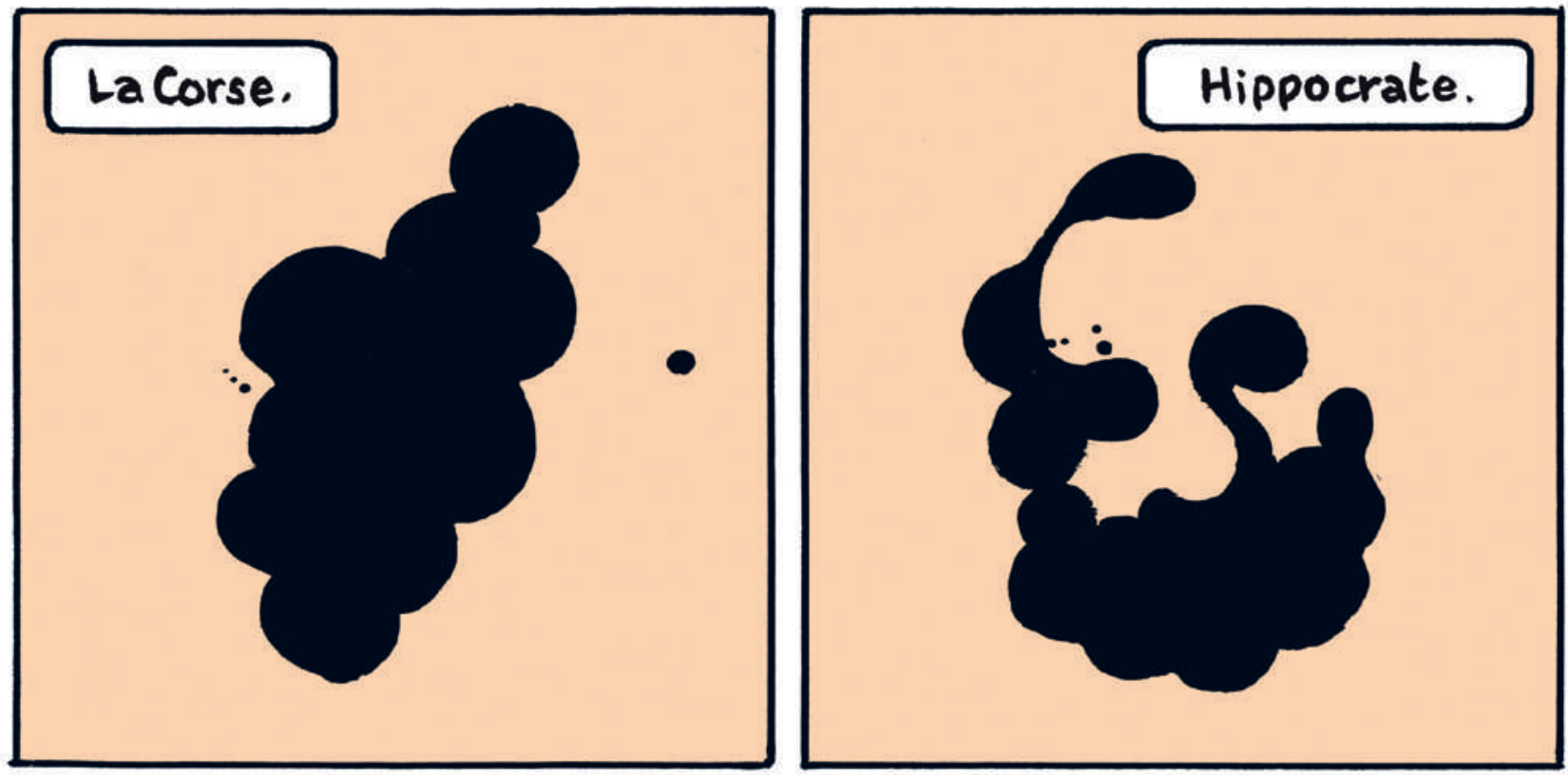

\section{de Willénus}
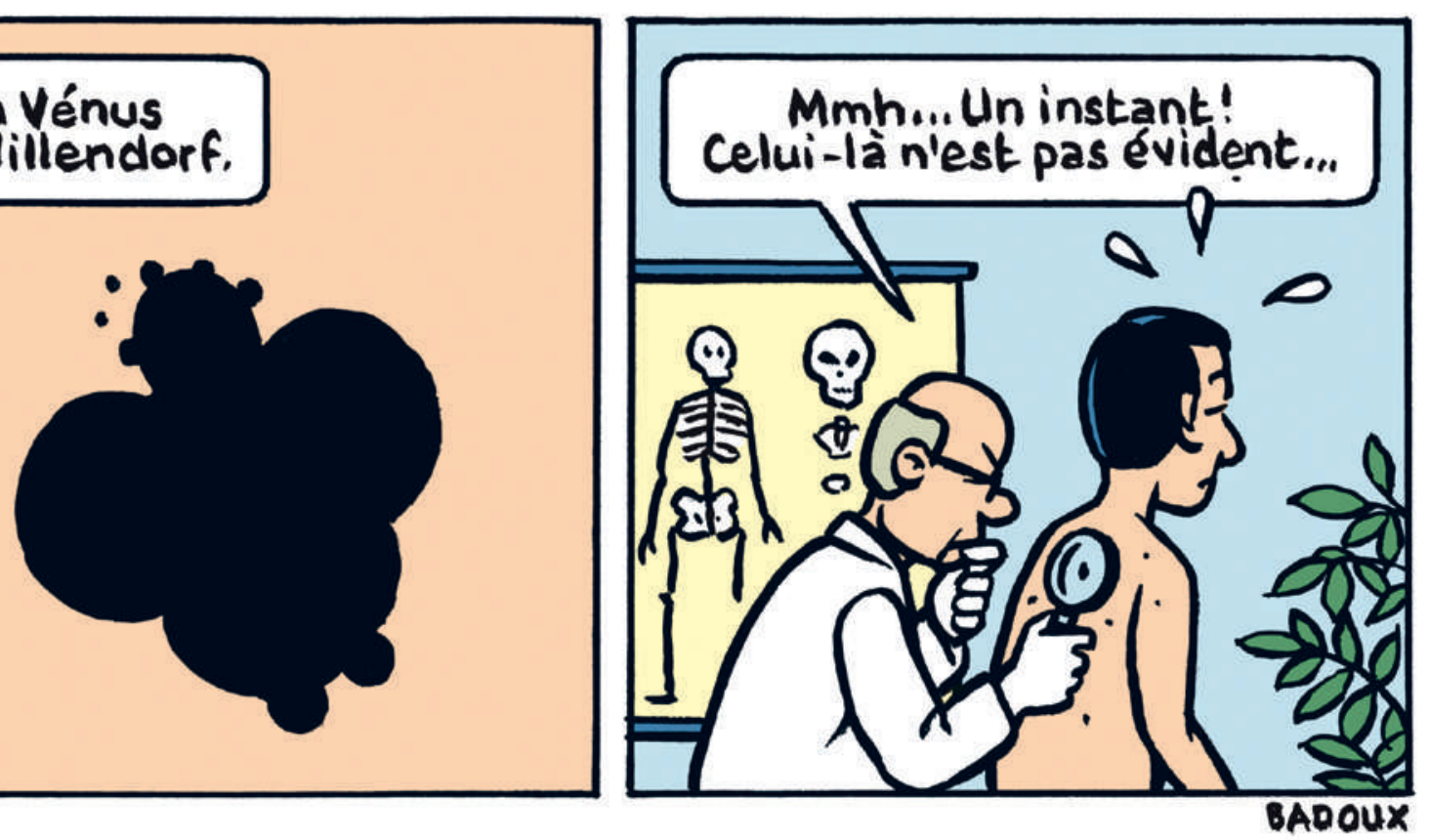